\title{
ВВП как стоимостной измеритель объема экономики и индикатор экономического роста
}

\author{
А.В. новиков, доктор экономических наук, Новосибирский \\ государственный университет экономики и управления «НИНХ». \\ E-mail: avnov59@yandex.ru \\ И.я. новиковА, кандидат экономических наук, Новосибирск. \\ E-mail:nov-iy@yandex.ru
}

\begin{abstract}
Аннотация. В статье рассматривается проблема измерения состояния экономики на основе существующих и предлагаемых показателей. Обсуждается соотношение понятий «экономическое развитие» и «экономический рост», выявляются их ключевые характеристики. Рассматриваются исторические аспекты создания показателя внутреннего валового продукта (ВВП), его значимость для оценки и сопоставления объектов наблюдения. В статье содержится аналитический материал по странам мира и отдельно по объединению БРИКС. Подчеркиваются особенности межстрановых сравнений по уровню ВВП. Анализируются недостатки показателя ВВП и направления его совершенствования, в том числе на основе использования индикаторов подлинного прогресса и скорректированных чистых накоплений, индексов человеческого развития, инклюзивного развития и счастья. Ключевые слова: экономическое развитие; экономический рост; ВВП; ВНД; G7; БРИКС; индикатор скорректированных чистых накоплений; индекс человеческого развития; индекс инклюзивного развития; индекс счастья
\end{abstract}

«Если рост ВВП (или спад) составляет от 0 до $2 \%$, о нем знают только статистики; при росте в диапазоне от 2 до $5 \%$ его ощущают бизнесмены в растущих секторах экономики; рост темпом 5-8\% в год ощущает большинство населения, и, наконец, темпы свыше 8\% дают феномен экономического чуда: когда такие темпы сохраняются в течение хотя бы десяти лет, страна переходит в другое качественное состояние». Яков Паппэ, автор книг, посвященных российским олигархам, формированию и развитию крупного бизнеса в России

\section{ВВП как целевой показатель}

Одной из целей развития России на среднесрочную перспективу провозглашено ее вхождение «в число пяти крупнейших экономик мира, обеспечение темпов экономического роста выше мировых при сохранении макроэкономической стабильности, в том числе инфляции на уровне, не превышающем $4 \%{ }^{1}$. Как

\footnotetext{
${ }^{1}$ Указ Президента РФ от 7 мая 2018 г. № 204 «О национальных целях и стратегических задачах развития Российской Федерации на период до 2024 года».
} 
войти в ТОП-5 мировых экономик? По какому показателю (показателям) экономика должна быть крупнейшей, и как эти показатели считаются? Квалифицированный ответ на эти вопросы осложняется в связи с развернувшейся в последние годы общественно-политической дискуссией о соотношении понятий экономического роста и экономического развития. Как они соотносятся? Возможен ли рост без развития или развитие без роста? Что их них является главной целью? Что нужно сделать, чтобы экономика характеризовалась ростом и отвечала критериям экономического развития?

В недалеком прошлом экономический рост и развитие считались взаимоувязанными понятиями. Экономический рост характеризовался динамикой ВВП/ВРП, а экономическое развитие оценивалось через темпы роста их производных - ВВП/ ВРП на душу населения, покупательной способности населения относительно ВВП/ВРП и т.д. Однако в настоящий период вновь ${ }^{2}$ появились сомнения в правильности такого подхода. Обязательно ли развитие обусловливается экономическим ростом? Вероятно, здесь многое зависит от того, какие стратегические цели ставит перед собой страна/регион. Например, если цель структурные преобразования в экономике, то на первоначальном этапе реформ их реализация вполне может привести к замедлению или отсутствию экономического роста. Более того, все чаще звучат высказывания о том, что в гармоничном обществе главной задачей является не рост экономики, а «состояние души», которое выражается в благополучии населения и общественном спокойствии.

Иными словами, дефиниции «экономический рост» и «экономическое развитие» необходимо четко разграничивать. Например, опираясь на базовую основу каждого из этих понятий. По мнению авторов, поиск ответа на вопрос о базовых постулатах, лежащих в основе экономического развития и экономического роста, находится в сфере анализа стратегий развития отдельных стран.

\footnotetext{
${ }^{2}$ На рубеже 1960-1970-х гг. группа западных интеллектуалов (Д. Медоус, П. Сэмюэлсон и др.), действующих под эгидой «Римского клуба», выдвинула теорию «нулевого роста», согласно которой оптимальным для развития страны является отсутствие роста основных макроэкономических показателей, прежде всего ВВП. Их позицию советские экономисты подвергли жесткой критике.
} 
Экономическое развитие основано на мобилизации ресурсов для достижения значимых для страны целей (например, борьбы с бедностью, в том числе через перераспределение доли оплаты труда в ВВП³), поэтому характеризующие его индикаторы должны отражать мобилизующий потенциал экономики. Экономический рост хотя и отражает степень динамизма экономики, не является самоцелью ее развития. В качестве его интегрального показателя обычно используется динамика ВВП [Титов, 2017; Новиков, Новикова, 2019]. При таком разграничении понятий развития и роста становится ясно, почему все чаще эксперты подвергают сомнению правомерность использования ВВП для оценки экономического развития.

\section{Показатель ВВП как объект дискуссий}

Еще в 2008 г. по поручению президента Франции Николя Саркози была создана Комиссия по измерению эффективности экономики и социального прогресса, в которую вошли два нобелевских лауреата - Д. Стиглиц и А. Сен, а также выдающийся французский экономист Ж.-П. Фитусси. Им было предложено выявить проблемы оценки эффективности экономик мира на основе показателя ВВП и сформулировать предложения по его совершенствованию. В своем итоговом докладе исследователи объяснили, «почему ВВП не имеет смысла» [Стиглиц и др., 2016]: выявлена ограниченность показателя ВВП в качестве индикатора экономического развития и социального прогресса, включая проблемы его измерения; нельзя использовать ВВП в качестве критерия оценки благосостояния, так как ВВП в основном измеряет рыночное производство, выраженное в денежных единицах.

Комиссия разработала рекомендации для измерения текущего благосостояния (уровень и качество жизни) и его сохранения в будущем (устойчивости) по трем основным направлениям.

1. Оценивать уровень жизни путем смещения акцента на другие агрегаты национальных счетов (например, на чистый валовой продукт, в котором учтена амортизация), при расчете классического ВВП путем улучшения измерения услуг, включая государственные, за счет рассмотрения в совокупности дохода,

\footnotetext{
${ }^{3}$ ВВП повышают зарплату // Коммерсантъ. 2019. 26 апр. № 75. C. 1. URL: https://www. kommersant.ru/doc/3955406 (дата обращения: 26.04.2019).
} 
потребления и богатства, а также вывода на первый план точки зрения домохозяйств.

2. Измерять качество благосостояния путем оценки в денежном выражении здоровья людей, их образования, персональной активности, включая работу, условий окружающей среды, политического представительства и управления, социальных связей и отношений, окружающей среды.

3. Оценивать устойчивость (будущее благосостояние) вместе с экологическими аспектами путем использования панели индикаторов устойчивого развития.

В свою очередь известный британский экономист Д. Койл показывает, что ВВП был хорошим показателем для экономики ХХ в., но все менее подходит для ХХІ в., в котором определяющую роль играют инновации, услуги и нематериальные блага [Койл, 2016].

В докладе Credit Suisse «Есть ли будущее у ВВП?» ${ }^{4}$ (2018 г.) отмечается снижение роли ВВП как основного экономического показателя. По мнению авторов, это связано прежде всего с развитием цифровых технологий, растущей разницей в бизнес-моделях развитых и развивающихся стран. Они также отмечают, что для оценки благополучия общества необходимы показатели, которые учитывают вопросы экологии, социального взаимодействия и технологического прогресса, предлагая в качестве инструментов такой оценки ввести «зеленый» ВВП, индекс человеческого развития, или индекс счастья.

В российской печати развернута дискуссия об использовании ВВП как показателя, отражающего уровень и цель развития экономики [Зотин, 2018].

Некоторые авторы предлагают вообще его не считать и обратиться к альтернативным показателям, которые лучше отражают уровень развития ${ }^{5}$ Так, в 2016 г. на экономическом форуме в Давосе Дж. Стиглиц призвал инвестировать в человеческий капитал и перестать оглядываться на рост ВВП. По мнению нобелевского лауреата, «ВВП - плохой показатель экономического

\footnotetext{
${ }^{4}$ Есть ли будущее у ВВП: что придет на смену главному барометру экономики // URL: https://www.rbc.ru/economics/31/05/2018/5b0eb17b9a794717f59bbcad?from=main (дата обращения: 22.03.2019).

${ }^{5}$ Отменить ВВП - и дело с концом! Вольная экономика. URL: https:/zen.yandex. $\mathrm{ru} / \mathrm{media} /$ freeconomy/otmenit-vvp-i-delo-s-koncom-5c61b0331fabdc00afe7cf30 (дата обращения: 03.04.2019).
} 
развития, плохой показатель благосостояния, и важно понимать, что использование таких показателей сказывается на решениях: если измерять не то, можно сделать не то» ${ }^{6}$. И это заявление не единственное.

На ежегодных форумах в Давосе регулярно обсуждаются методики расчета ВВП, а также предлагаются подходы по формированию других показателей, пригодных для оценки экономики страны (например, индекса инклюзивного развития).

Учитывая возможные направления трансформации показателя ВВП, рассмотрим историю его создания, сущность и подходы к модернизации.

\section{Из истории создания ВВП как универсального измерителя объема экономики страны}

Трудно поверить, но до 1930-х гг. не было показателя, позволяющего измерять и сопоставлять вклад в экономику той или иной страны различных ее отраслей и регионов, тем более делать международные сравнения. Обычной практикой было сравнение произведенных товаров в натуральной форме, что частично позволяло судить о соотношении изучаемых объектов без детального учета их потребительских качеств, но не позволяло делать выводы о масштабах производства.

Поэтому экономисты обсуждали возможность создания показателя, который обладал бы следующими свойствами:

$\sqrt{ }$ был бы универсальным для всех объектов наблюдения: стран, отраслей, регионов и т.д.;

$\sqrt{ }$ давал бы стоимостную оценку, как в национальной валюте, так и в валюте, выбранной для таких сопоставлений;

$\sqrt{ }$ требовал бы минимальной трудоемкости расчетов и коррелировал с собираемыми показателями для оценки эффективности объектов наблюдения.

Первым такой показатель предложил Саймон Кузнец - американский экономист российского происхождения, нобелевский лауреат по экономике 1971 г. «за эмпирически обоснованное толкование экономического роста». Он предложил измерять произведенные продукты и оказанные услуги не только в натуральном,

${ }^{6}$ Джозеф Стиглиц призвал не считать ВВП показателем развития. URL: https://www. rbc.ru/economics/21/01/2016/56a0ed629a79471f9d12c9af (дата обращения: 22.03.2019). 
но и в стоимостном выражении, путем расчета стоимости произведенных продуктов и оказанных услуг в текущих ценах. Этот показатель был назван Gross Domestic Product (GDP) - Валовой Внутренний Продукт (ВВП ${ }^{7}$.

В бюджетном послании 1944 г. президент США Франклин Рузвельт впервые ввел идею расчета ВВП для оценки роста национальной экономики. С тех пор концепция использования ВВП как стоимостного показателя получила международное признание. К началу XXI века рост экономики и рост ВВП стали синонимами практически во всех странах.

Наряду с Саймоном Кузнецом первопроходцем в сфере разработки показателя ВВП считается англичанин Ричард Стоун, который получил Нобелевскую премию в 1984 г. «за новаторскую работу в области создания системы национальных счетов».

Система национальных счетов (СНС) представляет собой согласованный на международном уровне стандартный набор рекомендаций по определению показателей экономической деятельности, базирующихся на принципах экономической теории ${ }^{8}$. Ключевые концепции и определения системы (как и классификации и правила ведения счетов) носят универсальный характер и не зависят от конкретных экономических условий, в которых они применяются.

СНС позволяет проводить сопоставления по любым задаваемым параметрам и может быть основой для выявления закономерностей в развитии стран по выделенным критериям. Сегодня ключевыми областями ее применения являются мониторинг развития экономики, макроэкономический анализ и международные сопоставления, но она дает возможность рассчитать также показатели, отражающие экономическое развитие и экономический рост, что позволяет предполагать ее активное использование для создания новых оригинальных показателей, формирующих мировые и национальные цели.

\footnotetext{
${ }^{7}$ С. Кузнец также совершил революцию в методике статистического анализа национального дохода, выдвинул теорию о сглаживании социального неравенства по мере развития экономики, развил идеи Н. Кондратьева об экономических циклах [Абрамовиц, 1993].

${ }^{8}$ Система национальных счетов 2008 / Европейская комиссия, МВФ, ОЭСР, ООН, Всемирный банк. Нью-Йорк, 2012. URL: https://unstats.un.org/unsd/publication/seriesf/ SeriesF_2Rev5r.pdf
} 
Для справки ${ }^{9}$.

Основные макроэкономические показатели (агрегаты) CHC-2008: валовой внутренний продукт (ВВП); чистый внутренний продукт (ЧВП); валовой национальный доход (ВНД); чистый национальный доход (ЧНД); национальный располагаемый доход; национальное сбережение; национальное богатство. Валовым национальным доходом (ВНД) в системе национальных счетов в 1998 г. начали называть валовой национальный продукт (ВНП).

Валовой внутренний продукт (ВВП) - это сумма валовой добавленной стоимости всех резидентов-производителей в основных ценах плюс часть налогов на продукты (или весь итог) за вычетом субсидий, которая не включена в оценку выпуска. Далее, ВВП равен сумме конечного использования товаров и услуг (все виды использования, кроме промежуточного потребления) в ценах покупателей минус стоимость импорта товаров и услуг. Наконец, ВВП также равен сумме первичных доходов, выплаченных резидентами-производителями.

Валовой национальный доход (ВНД) определяется как ВВП, плюс оплата труда и доходы от собственности, подлежащие получению из-за границы, плюс налоги на производство и импорт за вычетом субсидий, получаемые из-за рубежа, минус оплата труда, доходы и налоги, подлежащие выплате за границу. Таким образом, ВНД отличается от ВВП на величину сальдо первичных доходов (зарплата, доходы от собственности) из-за границы.

Рассмотрим два основных аспекта применения ВВП: как универсального стоимостного показателя всех произведенных в стране товаров и услуг для международных сопоставлений и как индикатора экономического роста.

\section{Особенности сравнения стран по ВВП и ВНД}

В настоящее время для международного сопоставления ВВП используют три основных метода его оценки:

1) пересчет стоимостных показателей с использованием среднегодового валютного курса сравниваемых стран;

2) метод Атласа - применение сглаженного за три года валютного курса;

3) расчет паритетов покупательной способности (ППС $)^{10}$.

Используя базу открытых данных Всемирного банка, приведем рейтинги топ-20 стран по валовому внутреннему продукту (ВВП) и валовому национальному доходу (ВНД) в 2017 г. При этом первый показатель рассчитан по валютному курсу, второйпо методу Атласа.

\footnotetext{
${ }^{9}$ Система национальных счетов 2008. / Европейская комиссия, МВФ, ОЭСР, ООН, Всемирный банк. Нью-Йорк, 2012. URL: https://unstats.un.org/unsd/publication/seriesf/ SeriesF_2Rev5r.pdf.

${ }^{10}$ Система национальных счетов 2008 / Европейская комиссия, МВФ, ОЭСР, ООН, Всемирный банк. Нью-Йорк, 2012. URL: https://unstats.un.org/unsd/publication/seriesf/ SeriesF_2Rev5r.pdf
} 


\section{Таблица 1. Рейтинг стран мира по ВВП, рассчитанному путем пересчета по валютному курсу, и по ВНД на основе метода Атласа в 2017 г.}

\begin{tabular}{|c|c|c|c|c|c|c|c|}
\hline Ранг & Страна & $\begin{array}{c}\text { ВВП, } \\
\text { млн } \\
\text { долл. } \\
\text { США* }\end{array}$ & $\begin{array}{c}\text { Доля } \\
\text { в мире, } \\
\%\end{array}$ & Ранг & Страна & $\begin{array}{c}\text { ВНД, } \\
\text { млн } \\
\text { долл. } \\
\text { США** }\end{array}$ & $\begin{array}{c}\text { Доля } \\
\text { в мире, } \\
\%\end{array}$ \\
\hline 1 & США & 19390604 & 24,02 & 1 & США & 18980259 & 24,30 \\
\hline 2 & Китай & 12237700 & 15,16 & 2 & Китай & 12042906 & 15,42 \\
\hline 3 & Япония & 4872137 & 6,03 & 3 & Япония & 4888124 & 6,26 \\
\hline 4 & Германия & 3677439 & 4,55 & 4 & Германия & 3596609 & 4,61 \\
\hline 5 & Великобритания & 2622434 & 3,25 & 5 & Великобритания & 2675928 & 3,43 \\
\hline 6 & Индия & 2600818 & 3,22 & 6 & Франция & 2548257 & 3,26 \\
\hline 7 & Франция & 2582201 & 3,20 & 7 & Индия & 2405744 & 3,08 \\
\hline 8 & Бразилия & 2055506 & 2,55 & 8 & Италия & 1878330 & 2,40 \\
\hline 9 & Италия & 1934798 & 2,40 & 9 & Бразилия & 1800567 & 2,31 \\
\hline 10 & Канада & 1653043 & 2,05 & 10 & Канада & 1573492 & 2,01 \\
\hline 11 & $\begin{array}{l}\text { Российская } \\
\text { Федерация }\end{array}$ & 1577524 & 1,95 & 11 & Южная Корея & 1460492 & 1,87 \\
\hline 12 & Южная Корея & 1530751 & 1,90 & 12 & Россия & 1355593 & 1,74 \\
\hline 13 & Австралия & 1323421 & 1,64 & 13 & Испания & 1265880 & 1,62 \\
\hline 14 & Испания & 1311320 & 1,62 & 14 & Австралия & 1263489 & 1,61 \\
\hline 15 & Мексика & 1150888 & 1,43 & 15 & Мексика & 1112395 & 1,42 \\
\hline 16 & Индонезия & 1015539 & 1,26 & 16 & Индонезия & 934365 & 1,20 \\
\hline 17 & Турция & 851549 & 1,05 & 17 & Турция & 883098 & 1,13 \\
\hline 18 & Нидерланды & 826200 & 1,02 & 18 & Нидерланды & 791270 & 1,01 \\
\hline 19 & Саудовская Аравия & 686738 & 0,85 & 19 & Швейцария & 682059 & 0,87 \\
\hline 20 & Швейцария & 678887 & 0,84 & 20 & $\begin{array}{l}\text { Саудовская } \\
\text { Аравия }\end{array}$ & 661784 & 0,85 \\
\hline \multicolumn{8}{|l|}{$\ldots$} \\
\hline 32 & Южная Африка & 348872 & 0,43 & 36 & Южная Африка & 307963 & 1,72 \\
\hline \multicolumn{8}{|l|}{$\ldots$} \\
\hline & G7 & 36735656 & 45,50 & & G7 & 36140999 & 46,27 \\
\hline & БРИКС & 18820420 & 23,31 & & БРИКС & 17912773 & 22,94 \\
\hline \multicolumn{8}{|l|}{$\cdots$} \\
\hline & Мир & 80737576 & 100,00 & & Мир & 78101101 & 100,00 \\
\hline
\end{tabular}

Источники табл. 1, 2: World Development Indicators database, World Bank, 25 January 2019. Gross domestic product 2017. URL: https://databank.worldbank.org/ data/download/GDP.pdf

World Development Indicators database, World Bank, 25 January 2019. Gross national income 2017, Atlas method. URL: https://databank.worldbank.org/data/download/GNI.pdf

* Оценка на базе сглаженного за три года валютного курса.

** Метод Атласа разработан Всемирным банком для собственных целей. Описание метода Атласа можно найти в ежегоднике Всемирного банка World Development Indicators, в разд. Statistical Methods. 
Как следует из таблицы 1 , почти четверть мирового ВВП приходится на США. Близким к нему является совокупный ВВП объединения БРИКС (Бразилия, Россия, Индия, Китай, Южная Африка). Второе место в мире по объему ВВП занимает Китай (он же обеспечивает 65\% от совокупного ВВП БРИКС). Таким образом, при развитии интеграции объединения БРИКС и признании доминирующей роли Китая можно утверждать, что США и БРИКС являются относительно разнозначными «игроками» в формировании мирового ВВП. Место России - одиннадцатое в мире и четвертое в БРИКС, то есть если ориентироваться на эти измерители, де-факто перед нами должна стоять задача вхождения не в пятерку, а в десятку крупнейших экономик мира.

Отметим близкие, но не совпадающие значения в рассматриваемой группе стран по размеру ВВП и ВНД. Если первая пятерка стран по тому и другому показателю совпадает, то, начиная с шестого места, нет однозначного соответствия: ВНД иначе ранжирует страны, чем ВВП. Отдельные исследователи полагают, что этот показатель более точный, однако ВВП попрежнему доминирует в межстрановых сравнениях.

Другим принципиальным измерителем мощи экономики является показатель ВВП по ППС (табл. 2).

Примечательно, что при таком способе расчета США уступают Китаю первенство в мировом рейтинге, а доля БРИКС составляет почти треть от мирового ВВП. При этом страны БРИКС распределены крайне неравномерно: от 18,25\% у Китая до $0,60 \%$ у Южной Африки. Доля Китая в совокупном ВВП БРИКС составляет 57,4\%.

Россия в рейтинге ВВП по паритету покупательной способности выглядит значительно лучше, чем в рейтинге ВВП, рассчитанному по валютному курсу (2,99\% против 1,95\%), и занимает третье место среди стран БРИКС.

Также обратим внимание, что по этому показателю доля G7 и БРИКС является почти равной, так что если такой способ расчета брать как основной для сравнения стран, выводы об их экономическом потенциале будут иными, чем для первого рейтинга.

Собственно, указанная зависимость оценки ВВП от метода расчета и является главным объектом критики. Исследователи активно ищут другие показатели, обосновывая целевые установки, которые те должны отражать. 
Таблица 2. Рейтинг стран мира по ВВП, рассчитанному на основе паритета покупательной способности в 2017 г.

\begin{tabular}{|c|c|c|c|}
\hline Ранг & Страна & $\begin{array}{c}\text { ВВП (ППС), } \\
\text { млн международных долл. }\end{array}$ & Доля в мире,\% \\
\hline 1 & Китай & 23300783 & 18,25 \\
\hline 2 & США & 19390604 & 15,19 \\
\hline 3 & Индия & 9453706 & 7,41 \\
\hline 4 & Япония & 5487161 & 4,30 \\
\hline 5 & Германия & 4187583 & 3,28 \\
\hline 6 & Российская Федерация & 3817201 & 2,99 \\
\hline 7 & Индонезия & 3242769 & 2,54 \\
\hline 8 & Бразилия & 3240524 & 2,53 \\
\hline 9 & Франция & 2876060 & 2,25 \\
\hline 10 & Великобритания & 2856703 & 2,24 \\
\hline 11 & Италия & 2387357 & 1,87 \\
\hline 12 & Мексика & 2360263 & 1,85 \\
\hline 13 & Турция & 2141265 & 1,68 \\
\hline 14 & Южная Корея & 1972971 & 1,55 \\
\hline 15 & Саудовская Аравия & 1771385 & 1,39 \\
\hline 16 & Испания & 1769637 & 1,38 \\
\hline 17 & Канада & 1714447 & 1,34 \\
\hline 18 & Иран & 1691474 & 1,32 \\
\hline 19 & Таиланд & 1233854 & 0,97 \\
\hline 20 & Австралия & 1192066 & 0,93 \\
\hline \multicolumn{4}{|l|}{$\ldots$} \\
\hline 29 & Южная Африка & 765542 & 0,60 \\
\hline \multicolumn{4}{|l|}{$\ldots$} \\
\hline & G7 & 38899915 & 30,47 \\
\hline & БРИКС & 40577756 & 31,79 \\
\hline \multicolumn{4}{|l|}{$\ldots$} \\
\hline & Мир & 127661922 & 100,00 \\
\hline
\end{tabular}

*Международный доллар - условная расчётная денежная единица, которая вычисляется делением единицы валюты соответствующей страны на расчётный показатель паритета покупательной способности, которую доллар США имел внутри США в оговоренное время.

Подушевые показатели уровня ВВП (ВНД) используются главным образом для определения взносов стран в бюджеты международных организаций, условий предоставления финансовой и иной помощи, а также для расчета различных индексов. При этом место той или иной страны в мировом рейтинге 
по душевому ВНД, как и в случае с ВВП, во многом зависит от принятой методики (табл. 3).

Таблица 3. Рейтинг стран мира по ВНД на душу населения в 2017 г.

\begin{tabular}{|c|c|c|c|c|c|}
\hline Ранг & Страна & $\begin{array}{c}\text { ВНД (метод } \\
\text { Атласа), } \\
\text { долл. США }\end{array}$ & Ранг & Страна & $\begin{array}{c}\text { ВНд (ППС), } \\
\text { международ- } \\
\text { ных долл. }\end{array}$ \\
\hline & Пятерка лидеров & & & Пятерка лидеров & \\
\hline 1 & Швейцария & 80560 & 1 & Катар & 128050 \\
\hline 2 & Остров Мэн & 79910 & 2 & Макао (Китай) & 105790 \\
\hline 3 & Норвегия & 75990 & 3 & Сингапур & 90570 \\
\hline 4 & Макао (Китай) & 72050 & 4 & Бруней Даруссалам & 83760 \\
\hline 5 & Люксембург & 70260 & 5 & Кувейт & 83310 \\
\hline \multirow[t]{2}{*}{$\ldots$} & & & $\ldots$ & & \\
\hline & G7 & & & G7 & \\
\hline 8 & США & 58270 & 12 & США & 60200 \\
\hline 18 & Германия & 43490 & 18 & Германия & 51680 \\
\hline 19 & Канада & 42870 & 22 & Канада & 46070 \\
\hline 21 & Великобритания & 40530 & 24 & Япония & 44850 \\
\hline 24 & Япония & 38550 & 26 & Франция & 43790 \\
\hline 25 & Франция & 37970 & 27 & Великобритания & 42560 \\
\hline 28 & Италия & 31020 & 30 & Италия & 39640 \\
\hline \multirow[t]{2}{*}{$\ldots$} & & & $\ldots$ & & \\
\hline & БРИКС & & & БРИКС & \\
\hline 68 & Российская Федерация & 9230 & 56 & Российская Федерация & 24890 \\
\hline 71 & Китай & 8690 & 76 & Китай & 16760 \\
\hline 73 & Бразилия & 8600 & 82 & Бразилия & 15200 \\
\hline 91 & Южная Африка & 5430 & 91 & Южная Африка & 13090 \\
\hline 146 & Индия & 1800 & 124 & Индия & 6980 \\
\hline$\ldots$ & $\ldots$ & $\ldots$ & $\ldots$ & $\ldots$ & $\ldots$ \\
\hline \multirow[t]{6}{*}{190} & Бурунди & 280 & 187 & \begin{tabular}{|l|} 
Центральна Африканская \\
Республика
\end{tabular} & 730 \\
\hline & Мир & 10371 & & Мир & 16902 \\
\hline & Низкий доход & 774 & & Низкий доход & 2127 \\
\hline & Доход ниже среднего & 2118 & & Доход ниже среднего & 7163 \\
\hline & Доход выше среднего & 8197 & & Доход выше среднего & 17553 \\
\hline & Высокий доход & 40142 & & Высокий доход & 47575 \\
\hline
\end{tabular}

Источник: World Development Indicators database, World Bank, 25 January 2019. Gross national income per capita 2017, Atlas method and PPP. URL: http://data. worldbank.org/data-catalog/world-development-indicators. 
При сопоставимой выборке - 190 стран для расчета по методу Атласа и 187 стран по методу ППС - место конкретной страны существенно отличается.

Заметим, что ВВП (ВНД) на душу населения не отражает ни качество жизни, ни истинное положение дел в экономике, так как не учитывает, например, коэффициент Джини, характеризующий разрыв в доходах между богатыми и бедными [Койл, 2017].

Таким образом, все еще остается актуальным поиск такого показателя, который бы был пригоден для более адекватного определения значимости конкретного государства и отражал бы не только экономический рост.

\section{ВВП как индикатор экономического роста}

Как мы уже отмечали, в пункте 1 Указа Президента РФ №204 «О национальных целях и стратегических задачах развития Российской Федерации на период до 2024 года» целевой установкой развития страны выступает рост экономики, в качестве показателя для оценки этого роста назван валовой внутренний продукт. За его изменениями не просто внимательно следят, но и пытаются корректировать его значения, в том числе для сохранения общественного спокойствия. Так, например, Росстат за 11 месяцев 2018 г. объявил рост ВВП на 1,8\%, затем после корректировки показатель был увеличен до $2,3 \%{ }^{11}$. Такая трансформация активно обсуждается учеными: действительно ли не было учтено развитие отдельных отраслей или это пример манипуляций для приукрашивания действительного состояния экономики?

В таблице 4 приведены темпы роста ВВП стран, входящих в G7 и объединение БРИКС, в 2015-2018 гг.

Как видим, в основной доле стран наблюдается снижение темпов экономического роста, измеряемых ВВП. При этом в большей степени - в группе G7. В объединении БРИКС темпы роста значительно выше, кроме ЮАР и Бразилии. Спорным является показатель России (по указанным причинам). В бюллетене МВФ «Перспективы развития мировой экономики», опубликованном в январе 2019 г., отмечено, что мировой подъем замедлился, и

\footnotetext{
${ }_{11}^{11}$ Росстат сообщил о рекордном за шесть лет росте экономики. Ведомости. URL: https://www.vedomosti.ru/economics/articles/2019/02/04/793198-rosstat-soobschil-rekordnomza-roste (дата обращения: 02.04.2019).
} 
в 2018 г. составил 3,7\% (оценка). Ужесточение финансовых условий, высокий уровень государственной и частной задолженности (например, госдолг США на начало 2019 г. достиг 22 трлн долл.) будут способствовать тому, что в 2019 г. рост мировой экономики по прогнозу составит $3,5 \%$, а в 2020 г. $-3,6 \%{ }^{12}$.

Таблица 4. Динамика реального объема валового внутреннего продукта* стран, входящих в G7 и БРИкС, в 20152018 гг., \% к предыдущему периоду, прирост (снижение)

\begin{tabular}{|l|c|c|c|c|}
\hline \multicolumn{1}{|c|}{ Страна } & $\mathbf{2 0 1 5}$ & $\mathbf{2 0 1 6}$ & $\mathbf{2 0 1 7}$ & $\mathbf{2 0 1 8}^{\text {** }}$ \\
\hline США & & & & \\
\hline Канада & 2,9 & 1,6 & 2,2 & 2,9 \\
\hline Франция & 0,7 & 1,1 & 3,0 & 2,1 \\
\hline Великобритания & 1,1 & 1,2 & 2,2 & 1,5 \\
\hline Германия & 2,3 & 1,8 & 1,8 & 1,4 \\
\hline Италия & 1,7 & 2,2 & 2,4 & 1,4 \\
\hline Япония & 0,9 & 1,1 & 1,6 & 1,0 \\
\hline & 1,2 & 0,6 & 1,9 & 0,7 \\
\hline \multicolumn{1}{|c|}{ БРИКС } & & & & \\
\hline Кндия & 8,2 & 7,1 & 6,7 & 7,3 \\
\hline Россия & $-2,5$ & 6,7 & 6,9 & 6,6 \\
\hline Бразилия & $-3,5$ & 0,3 & 1,6 & 2,3 \\
\hline ЮАР & 1,3 & 0,3 & 1,1 & 1,3 \\
\hline
\end{tabular}

Источник: Росстат. URL: http://www.gks.ru/bgd/free/B09_03/lssWWW.exe/Stg/ d04/31.htm

* Информация подготовлена на основе публикаций Международного валютного фонда, Организации экономического сотрудничества и развития, Евростата и оперативных данных национальных статистических служб.

** Предварительные данные.

В целом, следует отметить, что динамика ВВП хотя и остается основным показателем экономического роста страны, но а) не единственным и б) ее анализ должен быть подкреплен анализом факторов, влияющих на эту динамику. Поэтому, несмотря на развитую методологическую и методическую базу расчета экономического роста, поиск альтернативных ВВП показателей продолжается. Рассмотрим основные предложения.

\footnotetext{
${ }^{12}$ Международный валютный фонд, 2019. Бюллетень «Перспектив развития мировой экономики», январь 2019 года. Ослабление мирового подъема. URL: https:/www.imf. org/ru/Publications/WEO/Issues/2019/01/11/weo-update-january-2019 (дата обращения: 23.02.2019).
} 


\section{Оценка уровня благосостояния и устойчивого развития: скорректировать или заменить ВВП}

Очевидно, что переход на иные показатели (помимо ВВП), отражающие экономический рост и экономическое развитие, должен иметь обоснованные причины. Кому-то таковым может представляться, например, улучшение положения той или иной страны или группы стран в общемировом рейтинге. Однако, на наш взгляд, гораздо важнее - поиск взаимосвязей в стратегиях отдельных стран, выявление тенденций формирования мировой экономики и новых постулатов, отражающих общественно-экономический прогресс.

Зарубежные исследования в сфере корректировки ВВП и поиска новых индикаторов экономического роста были начаты еще в 1970-х г. Нордхаусом и Тобином [Леочи, 2012]. Эти экономисты предложили рассчитывать путем корректировки ВВП два показателя: меру экономического благосостояния (Measure of Economic Welfare-MEW) и меру устойчивого экономического благосостояния (Sustainable Measure of Economic Welfare-SMEW).

Показатель $\boldsymbol{M E} \boldsymbol{W}$ определялся путем исключения из суммарного частного потребления затрат, которые не вносят позитивного вклада в благосостояние (например, государственные расходы на национальную оборону, затраты на поездки на работу и юридические услуги), и добавления денежных оценок деятельности, которая вносит такой вклад (например, досуг или работа на дому).

Показатель $\boldsymbol{S M E} \boldsymbol{W}$ определялся Нордхаусом и Тобином путем корректировки показателя $\boldsymbol{M} \boldsymbol{E} \boldsymbol{W}$ на изменения в суммарном богатстве. Для этого были использованы оценки суммарного общественного и частного богатства, включая воспроизводимый капитал (оборудование, инфраструктура), невоспроизводимый (земля и иностранные активы), образовательный (кумулятивная стоимость лет, проведенных в образовательной системе) и оздоровительный капитал.

Позднее на основе MEW и SMEW были разработаны индекс устойчивого экономического благосостояния (Index of Sustainable Economic Welfare-ISEW) и индикатор подлинного прогресса (Genuine Progress Indicator - GPI), которые дополнительно учитывают также фактор истощения природных ресурсов (загрязнение воды и воздуха, уровень шума, потерю природных 
ресурсов и т.п.). Истощение ресурсов оценивается путем определения объема инвестиций, необходимых для создания потока возобновляемых заместителей. Имеются данные, что в 1990-х годах около 11 стран рассчитывали национальный индикатор подлинного прогресса. Для ЕС и США этот индикатор показал устойчивое сокращение благосостояния.

Еще одной альтернативой ВВП является так называемый «зеленый» ВВП. Для его подсчета в традиционный ВВП вносятся корректировки, касающиеся истощения ресурсов, расходов на защиту и восстановление окружающей среды. В начале 2000-х годов были проведены «пробные» расчеты этого показателя для ряда стран, включая Россию. Полученные результаты показали, что вместо экономического роста в этих странах происходит стагнация или снижение, поэтому, по политическим соображениям, они не получили широкого освещения, а «зеленый» ВВП не занял место классического ${ }^{13}$. Кроме того, некоторые аналитики признают, что при расчете этого показателя возникают проблемы с достоверностью стоимостных оценок качества окружающей среды [Стиглиц и др., 2016. С. 172].

Тем не менее в 2009 г. специалистами из ООН в соавторстве с МВФ, ОЭСР, Всемирным банком и ВТО был представлен доклад о зеленой экономике, провозглашающий глобальный «зеленый курс» как единственный путь развития, способный придать мировым системам устойчивость.

На концепции «зеленых национальных счетов» построен еще один индикатор, которым предлагалось заменить ВВП. Это - скорректированные чистые накопления (Adjusted Net Savings-ANS), также известные как истинные сбережения, или истинные инвестиции. Теоретической основой этого индикатора является поддержание постоянного запаса «богатства в расширенном понимании», которое не ограничивается природными ресурсами, но включает в себя также физический, производственный и человеческий капитал. ANS - это показатель объема накоплений, из которого вычитаются расходы на потребление, стоимость, отражающая масштабы истощения природных ресурсов, ущерб от выбросов углерода, и прибавляются затраты

${ }^{13}$ Шаповалов А. Тайна зеленого ВВП // Коммерсантъ Власть. 2010. 26 апр. № 16. С. 46. URL: https://www.kommersant.ru/doc/1357612 (дата обращения: 22.03.2019). 
государства на образование. Отрицательное значение ANS означает истощение запасов капитала, положительное - увеличение богатства. Индикатор скорректированных чистых накоплений рассчитывается Всемирным банком для более чем 200 стран. Заметим, что значение этого индикатора для России в отдельные годы было отрицательным.

Основная проблема введения указанных альтернативных показателей заключается не в том, что они дают худшее представление об экономическом росте, чем ВВП, а в том, что они не могут рассчитываться, корректироваться и прогнозироваться с такой же регулярностью ввиду отсутствия официальных статистических данных. Нет регулярной статистики по образовательному и оздоровительному капиталу, экологическому ущербу и истощению природных ресурсов. Поэтому все они могут дополнить ВВП, но не заменить его [Стиглиц и др., 2016].

К интегральным показателям, которые предлагается использовать в качестве альтернативы ВВП, относится ряд индексов. Один из самых известных - индекс человеческого развития (Human Development Index, HDI) - был разработан в 1990 г. пакистанским экономистом Махбубом уль-Хаком (Mahbub ul-Haq) и с тех пор ежегодно рассчитывается экспертами Программы развития $\mathrm{OOH}(П Р \mathrm{OOH})$ совместно с группой независимых экспертов. Индекс человеческого развития - это интегральный показатель, который измеряет достижения страны в области состояния здоровья, получения образования и доходов её граждан, по трём основным направлениям, для которых рассчитываются следующие индексы.

Индекс ожидаемой продолжительности жизни характеризует здоровье и долголетие граждан страны, измеряемое показателем средней ожидаемой продолжительности жизни при рождении.

Индекс образования характеризует доступ к образованию, измеряемый средней ожидаемой продолжительностью обучения детей школьного возраста и средней продолжительностью обучения взрослого населения.

Индекс валового национального дохода характеризует уровень жизни, измеряемый величиной валового национального дохода на душу населения в долларах США по паритету покупательной способности. 
Основная идея состоит в том, чтобы при оценке развития учитывались достижения в области здравоохранения и образования. В 2010 г. индекс человеческого развития был трансформирован. В дополнение к сводному показателю, который опирается на среднестрановые статистические данные и не учитывает внутреннее неравенство, были введены три новых индикатора: индекс человеческого развития, скорректированный с учётом социально-экономического неравенства (ИЧРН), индекс гендерного неравенства (ИГН) и индекс многомерной бедности (ИМБ).

В таблице 5 приведены позиции некоторых стран в рейтинге по индексу человеческого развития в 2017 г. (вся выборка включает 189 стран).

Таблица 5. Позиции стран мира в рейтинге по индексу человеческого развития (HDI) в 2017 г.

\begin{tabular}{|c|c|c|c|}
\hline Страна & $\begin{array}{l}\text { Место в рей- } \\
\text { тинге }\end{array}$ & $\begin{array}{c}\text { Зна- } \\
\text { чение } \\
\text { индекса }\end{array}$ & Группа стран \\
\hline & Пятерка лидеров & & \\
\hline Норвегия & $1-e$ & 0,953 & С очень высоким уровнем человеческого развития \\
\hline Швейцария & $2-e$ & 0,944 & С очень высоким уровнем человеческого развития \\
\hline Австрия & $3-e$ & 0,939 & С очень высоким уровнем человеческого развития \\
\hline Ирландия & 4-e & 0,938 & С очень высоким уровнем человеческого развития \\
\hline \multirow[t]{2}{*}{ Германия } & $5-e$ & 0,936 & С очень высоким уровнем человеческого развития \\
\hline & G7 & & \\
\hline Германия & $5-e$ & 0,936 & С очень высоким уровнем человеческого развития \\
\hline Канада & $12-\mathrm{e}$ & 0,926 & С очень высоким уровнем человеческого развития \\
\hline США & 13-e & 0,924 & С очень высоким уровнем человеческого развития \\
\hline Великобритания & 14-e & 0,922 & С очень высоким уровнем человеческого развития \\
\hline Япония & $19-\mathrm{e}$ & 0,909 & С очень высоким уровнем человеческого развития \\
\hline Франция & 24-e & 0,901 & С очень высоким уровнем человеческого развития \\
\hline \multirow[t]{2}{*}{ Италия } & $28-\mathrm{e}$ & 0,880 & С очень высоким уровнем человеческого развития \\
\hline & БРИКС & & \\
\hline Россия & $49-\mathrm{e}$ & 0,816 & С очень высоким уровнем человеческого развития \\
\hline Бразилия & 79 -e & 0,759 & С высоким уровнем человеческого развития \\
\hline Китай & $86-\mathrm{e}$ & 0,752 & С высоким уровнем человеческого развития \\
\hline ЮAP & $113-\mathrm{e}$ & 0,699 & Со средним уровнем человеческого развития \\
\hline Индия & $130-\mathrm{e}$ & 0,640 & Со средним уровнем человеческого развития \\
\hline
\end{tabular}

Источник: Доклад «Индексы и индикаторы человеческого развития: Обновленные статистические данные 2018». Опубликовано для Программы развития Организации Объединенных Наций (ПРООН). URL: http://hdr.undp.org/sites/ default/files/2018_human_development_statistical_update_ru.pdf 
Как видим, в пятерку лидеров из стран G7 вошла только Германия. В целом, группы G7 и БРИКС характеризуются неравномерным распределением внутри себя. При этом страны БРИКС существенно отстают от развитых стран. Приятно отметить, что Россия лидирует среди стран БРИКС и вошла в группу 59 стран с очень высоким уровнем человеческого развития. Замыкает рейтинг стран БРИКС Индия, которая находится на 130-м месте и отстает от России на 81 позицию в рейтинге и на 0,176 пункта в значении индекса.

Приведенные данные дают широкий простор для формирования целевых показателей для отдельных стран, в случае выбора ими в качестве стратегической цели человеческое развитие.

Индекс инклюзивного развития. Для решения проблемы социально-экономического неравенства международными и наднациональными организациями, такими как $\mathrm{OOH}, \mathrm{MB}$, ОЭСР, Всемирный банк, Всемирный экономический форум, стал использоваться показатель инклюзивного (или социальноориентированного) экономического роста, для которого были разработаны специальные методики [Андриевская, 2015].

Разработанный Всемирным экономическим форумом индекс инклюзивного развития (Inclusive Development Index - IDI) позволяет оценить, насколько эффективно общенациональное богатство повышает уровень жизни и способствует сглаживанию дифференциации среди населения. Индекс включает 12 индикаторов, объединенных в три группы:

1) рост и развитие (ВВП на душу населения, производительность труда, занятость, ожидаемая продолжительность жизни);

2) инклюзивность (средний семейный доход, уровень неравенства доходов, уровень бедности, уровень неравенства в распределении богатства);

3) межпоколенческая справедливость и устойчивость (уровень сбережений, демографической нагрузки, государственного долга и загрязнения окружающей среды).

ВЭФ ранжирует по IDI отдельно развитые и развивающиеся страны. Это потребовалось из-за различий между ними в определении уровня бедности. В таблице 6 приведены позиции отдельных стран мира в рейтинге в 2017-2018 гг.

В настоящее время известно несколько организаций, которые разрабатывают и публикуют так называемый индекс сцастья. 
К ним относятся Сеть решений устойчивого развития ООН (World Happiness Index - WHI), британский исследовательский центр New Economic Foundation (Happy Planet Index-HPI), Организация экономического сотрудничества и развития (OECD Better Life Index $)^{14}$.

Таблица 6. Позиции стран мира в рейтинге по индексу инклюзивного развития (IDI) в 2017, 2018 гг.

\begin{tabular}{|c|c|c|}
\hline Страна & 2018 & 2017 \\
\hline Развитые страны, всего & 30 & 29 \\
\hline \multicolumn{3}{|l|}{ Пятерка лидеров } \\
\hline Норвегия & 1 & 1 \\
\hline Исландия & 2 & 4 \\
\hline Люксембург & 3 & 2 \\
\hline Швейцария & 4 & 3 \\
\hline Дания & 5 & 5 \\
\hline \multicolumn{3}{|l|}{ G7 } \\
\hline Германия & 12 & 13 \\
\hline Канада & 17 & 15 \\
\hline Франция & 18 & 18 \\
\hline Великобритания & 21 & 21 \\
\hline Япония & 24 & 24 \\
\hline США & 23 & 23 \\
\hline Италия & 27 & 27 \\
\hline Развивающиеся страны, всего & 77 & 78 \\
\hline \multicolumn{3}{|l|}{ Пятерка лидеров } \\
\hline Литва & 1 & 1 \\
\hline Венгрия & 2 & 3 \\
\hline Азербайджан & 3 & 2 \\
\hline Латвия & 4 & 7 \\
\hline Польша & 5 & 4 \\
\hline \multicolumn{3}{|l|}{ БРИКС } \\
\hline Россия & 19 & 13 \\
\hline Китай & 26 & 15 \\
\hline Бразилия & 37 & 30 \\
\hline Индия & 62 & 60 \\
\hline Южная Африка & 69 & 70 \\
\hline
\end{tabular}

Источники: The Inclusive Growth and Development Report 2017. World Economic Forum 2017. URL: http://www3.weforum.org/docs/WEF_Forum_IncGrwth_2017.pdf;

The Inclusive Development Index 2018. Summary and Data Highlights. World Economic Forum 2018. URL: http://www3.weforum.org/docs/WEF_Forum_IncGrwth_2018.pdf

14 Уровень счастья как новый показатель ВBП. URL: http://2035.media/2019/01/09/ happy/ (дата обращения: 17.01.2019). 
Как видим, состав топ-5 развитых стран в последние два года не изменился. В пятерку лидеров среди развивающихся стран входят бывшие советские республики и страны соцлагеря. Россия по индексу инклюзивного развития среди стран БРИКС занимает первое место, значительно опережая не только партнеров по альянсу, но и США. То есть в случае принятия индекса инклюзивного развития в качестве измерителя положения стран ситуация России на мировой арене выглядела бы значительно лучше.

Наиболее известными и представительными являются исследования ООН, которые публикуются, начиная с 2012 г., в ежегодном Докладе о мировом счастье (World Happiness Report). При определении уровня счастья для 156 стран исследователями анализируются шесть показателей: ВВП на душу населения; ожидаемая продолжительность здоровой жизни; масштабы социальной поддержки; возможность граждан самостоятельно принимать жизненно важные решения; щедрость; восприятие коррупции.

В таблице 7 приведены рейтинг стран и значения индекса счастья в 2018 г. (выборка 156 стран).

Таблица 7. Позиции стран мира в рейтинге счастья в 2018 г.

\begin{tabular}{|c|c|c|}
\hline Страна & Место в рейтинге & Значение индекса \\
\hline \multicolumn{3}{|c|}{ Пятерка лидеров } \\
\hline Финляндия & 1 & 7,769 \\
\hline Дания & 2 & 7,600 \\
\hline Норвегия & 3 & 7,554 \\
\hline Исландия & 4 & 7,494 \\
\hline Нидерланды & 5 & 7,488 \\
\hline \multicolumn{3}{|c|}{ G7 } \\
\hline Канада & 9 & 7,278 \\
\hline Великобритания & 15 & 7,054 \\
\hline Германия & 17 & 6,985 \\
\hline США & 19 & 6,892 \\
\hline Франция & 24 & 6,592 \\
\hline Италия & 36 & 6,223 \\
\hline Япония & 58 & 5,886 \\
\hline \multicolumn{3}{|c|}{ БРИКС } \\
\hline Бразилия & 32 & 6,300 \\
\hline Россия & 68 & 5,648 \\
\hline Китай & 93 & 5,191 \\
\hline ЮAP & 106 & 4,722 \\
\hline Индия & 140 & 4,015 \\
\hline
\end{tabular}

Источник: World Happiness Report 2019. URL: http://www.worldhappiness.report/ 
Как видим, в пятерку лидеров по индексу счастья не попали представители ни группы G7, ни стран БРИКС. При этом внутри этих групп наблюдается значительный разброс показателей. Так, Япония отстает от Канады на 49 мест в рейтинге, а Бразилия не только занимает первое место среди стран БРИКС, но и обошла Италию и Японию. Также отметим, что Россия занимает второе место по индексу счастья среди стран БРИКС и только на 10 мест ниже Японии.

Приведенные данные показывают, что индекс счастья выстраивает страны мира в непривычной исследователям конфигурации и заставляет задуматься о возможной смене приоритетов при определении места и роли той или иной страны в мировом развитии.

Таким образом, спустя почти 90 лет после создания показателя ВВП разворачивается дискуссия о новых индикаторах, измеряющих благополучие экономики и общества. Не исключено, что в ближайшие годы мы станем свидетелями внедрения новых показателей.

В зависимости от выбора в качестве цели стратегического развития конкретных показателей, отражающих различные аспекты существования человека и общества, результаты, формирующие нашу оценку места и роли той или иной страны в глобальном мире, будут различны. Именно о смене приоритетов в XXI веке ведутся основные дискуссии в экспертном сообществе.

Поэтому, уточняя цели реализации Указа Президента РФ от 7 мая 2018 г. № 204 «О национальных целях и стратегических задачах...», следует иметь в виду, что Россия, прежде всего, должна предложить адекватную национальным целям систему показателей. Выбор такой системы - ключевой вопрос при определении стратегии развития. Эти показатели могут отражать исторические особенности той или иной страны, уровень образования и культуры и т.д. На наш взгляд, эти особенности необходимо учитывать при оценке экономического развития и экономического роста любых государств.

\section{Литература}

Абрамовиц М. Биография. Саймон Кузнец (1901-1985) // Теория и история экономических и социальных институтов и систем (THESIS). Структуры и институты, 1993. Вып. 2. С. 228-234. 
Андриевская В.Б. Эффективность государственного управления как необходимая предпосылка инклюзивного роста экономики // Идеи и идеалы. 2015. № 1(23). Т. 2. С. 90-101.

Зотин А. Экономика протеста: валовой внутренний обман // Коммерсантъ. 2018. 25 авг. URL: https://www.kommersant.ru/doc/3712555?from=doc_vrez

Койл Д. ВВП: Краткая история, рассказанная с пиететом / Пер. с англ. А. Гусева; под науч. ред. А. Смирнова; НИУ «Высшая школа экономики». М.: Изд. Дом Высшей школы экономики, 2016. 176 с.

Леочи П. Качество жизни и устойчивое развитие // Экономические науки 2012. № 5 (90). C. 41-45. URL: http://ecsocman.hse.ru/ data/2013/02/13/1251421871/99.pdf

Новиков А.В., Новикова И.Я. Экономический рост и инвестиционная деятельность в России: прогнозы и реальность // ЭКО. 2019. № 2. С. 104-122.

Стиглии Д., Сен А., Фитусси Ж.-П. Неверно оценивая нашу жизнь: Почему ВВП не имеет смысла? Доклад Комиссии по измерению эффективности экономики и социального прогресса / Пер. с англ. И. Кушнаревой; науч. ред. перевода Т. Дробышевская. М.: Изд-во Института Гайдара, 2016. 216 с.

Титов Б. Стратегия роста для России [Эл. ресурс] / Б. Титов, А. Широв // Вопросы экономики. 2017. № 12. С. 24-39. URL: https://dlib.eastview.com/ browse/doc/50030095.

Статья поступила 11.04.2019.

Для цитирования: Новиков А.В., Новикова И.Я. ВВП как стоимостной измеритель объема экономики и индикатор экономического роста// ЭКО. № 9. C. 165-187. DOI: 10.30680/ECO0131-7652-2019-9-165-187.

\section{Summary}

Novikov, A.V., Doct. Sci. (Econ.), Novosibirsk state University of Economics and Management,

Novikova, I. Ya., Cand. Sci. (Econ.), Novosibirsk

Gdp as the Value of Measuring the Size of the Economy and the Country's Economic Growth

Abstract. The article analyzes the problem of measuring the state of the economy on the basis of existing and proposed indicators. The relationship between the concepts of "economic development" and "economic growth" is discussed. The main aspects characterizing economic development and economic growth are revealed. The historical aspects of the creation of the gross domestic product (GDP) indicator, its importance for the evaluation and comparison of objects of observation are considered. The main directions of improving GDP and fundamental approaches to the transition to another indicator are highlighted. The article contains a large analytical material on the countries of the world and separately on the BRICs group. Highlighted features of the comparison countries in terms of GDP. The paper analyzes the shortcomings of the GDP indicator and the directions of its improvement, including indicators of real progress and adjusted net savings, Indices of human development, inclusive development and happiness. 
Keywords: economic development; economic growth; GDP; GNI; BRICS; Adjusted net savings indicator; human development Index; inclusive development Index; G7; Happiness inde

\section{References}

Abramovits, M. (1993). Biography. Simon Kuznets (1901-1985). Teoriya $i$ istoriya ehkonomicheskikh $i$ sotsial'nykh institutov $i$ sistem. Struktury $i$ instituty. Theory and History of Economic and Social Institutions and Systems (THESIS), Vyp. 2. Pp. 228-234. (In Russ.).

Andrievskaya, V.B. (2015). Efficiency of public administration as a necessary prerequisite for inclusive economic growth. Idei i idealy. Ideas \& Ideals. No. 1(23). Vol. 2. Pp. 90-101. (In Russ.).

Zotin, A. (2018). Protest economy: gross domestic fraud. Kommersant 25 aug. (In Russ.). Available at: https://www.kommersant.ru/doc/3712555?from=doc_vrez (accessed 22.03.2019).

Koil, D. (2016). GDP: a brief history told with piety. TRANS. from English. A. Guseva; under the science edited by A. Smirnov; national research UNIVERSITY "Higher school of Economics". Moscow. House of Higher school of Economics Publ. 176 P. (In Russ.).

Leochi, P. (2012). Quality of life and sustainable development. Ehkonomicheskie nauki. No. 5 (90). Pp. 41-45. (In Russ.). Available at: http://ecsocman.hse.ru/ data/2013/02/13/1251421871/99.pdf (accessed 10.04.2019).

Novikov, A.V., Novikova, I. Ya. (2019). Economic growth and investment activity in Russia: forecasts and reality. ECO. No. 2. Pp. 104-122. (In Russ.).

Stiglits, D., Sen, A., Fitussi, Zh.-P. (2016). Incorrectly assessing our lives: Why GDP doesn't make sense? Report of the Commission on measuring economic performance and social progress. Moscow. Publishing house of the Gaidar Institute, 216 P. (In Russ.).

Titov, B. (2017). Growth strategy for Russia. Voprosy ehkonomiki. No. 12. Pp. 24-39. (In Russ.). Available at: https://dlib.eastview.com/browse/doc/50030095 (accessed 18.04.2019).

For citation: Novikov, A. V., Novikova, I. Ya. (2019). Gdp as the Value of Measuring the Size of the Economy and the Country's Economic Growth. ECO. No. 9. Pp. 165-187. (In Russ.). DOI: 10.30680/ECO0131-7652-2019-9-165-187. 